\title{
Babacan Liderlik Tarzının Çalışan Görev Performansı ve Duygusal Bağlılık Üzerindeki Etkisi

\author{
(The Effect of Paternalistic Leadership Style on Employee Task Performance and \\ Emotional Commitment)
}

\author{
Zeynep HATIPOĞLU iDa Gülbeniz AKDUMAN iDb Bülent DEMİR \\ a Nişantaşı Üniversitesi, İstanbul, Türkiye. zhatipoglu@gmail.com \\ b Fatih Sultan Mehmet Vakıf Üniversitesi, İstanbul, Türkiye. gulbeniz@akduman.com \\ c İstanbul Arel Üniversitesi, İstanbul, Türkiye. demirbtr@gmail.com
}

\begin{tabular}{|c|c|}
\hline MAKALE BİLGİSİ & ÖZET \\
\hline $\begin{array}{l}\text { Anahtar Kelimeler: } \\
\text { Babacan Liderlik } \\
\text { Görev Performansı } \\
\text { Duygusal Bağlllık } \\
\text { Gönderme Tarihi } 30 \text { Kasım } 2018 \\
\text { Revizyon Tarihi } 28 \text { Şubat } 2019 \\
\text { Kabul Tarihi } 10 \text { Mart } 2019\end{array}$ & $\begin{array}{l}\text { Amaç - Bu çalışmanın amacı babacan liderlik tarzının çalışanın görev performansı ve duygusal } \\
\text { bağlılık üzerindeki etkisinin incelemektir. } \\
\text { Yöntem - Araştırmada, olasılığa dayalı olmayan ve herkesi örneğe dahil edilebilme imkanı } \\
\text { sağladığı için çok yaygın kullanılan kolayda örnekleme yöntemi tercih edilmiştir. Kolayda } \\
\text { örnekleme yöntemiyle çevrimiçi olarak ulaşılan ve farklı sektörlerde } 200 \text { çalışana uygulanan } \\
\text { anket formlarının tamamı örnekleme dahil edilmiştir. Verilerin analizinde SPSS (Statistical } \\
\text { Package Program for Social Science) } 21.0 \text { programı kullanılmıştır. Çarpıklı (Skewness) } \\
\text { katsayısı ölçek puanlarının normallik sınaması için kullanılmıştır. Ölçek puanları normal } \\
\text { dağılım gösterdiği için ölçek ve alt boyut puanlarının cinsiyet ve doğum tarihine (kuşak) göre } \\
\text { karşılaştırılmasında bağımsız iki örneklem t testi; mevcut şirketteki çalışma süresine göre } \\
\text { karşılaştırılmasında tek yönlü varyans analizi (ANOVA) kullanılmıştır. ANOVA testinde } \\
\text { anlamlı farklılık görüldüğünde farkın hangi iki grup arasında olduğunu analiz etmek için LSD } \\
\text { post hoc testi kullanılmıştır. Değişkenler arasındaki ilişki analizi için Pearson korelasyon } \\
\text { analizinden; babacan liderlik tarzının çalışan performansı ve duygusal bağlılık üzerindeki } \\
\text { etkisini analiz etmek için regresyon analizi kullanılmıştır. Analizlerdeki güven aralığ1 \%95'dir. } \\
\text { (p<0,05) } \\
\text { Bulgular - Yapılan istatistiksel analizler doğrultusunda; çalışanların babacan liderlik algılarının } \\
\text { yükselmesinin çalışanın görev performansını artırdığı ve duygusal bağlllıklarını güçlendirdiği } \\
\text { sonucuna ulaşılmıştır. Ancak duygusal bağlılık düzeyinin X kuşağı çalışanlarda Y kuşağı } \\
\text { çalışanlardan daha fazla olduğu ve aynı işyerinde on yıldan daha uzun süre çalışan kişilerin } \\
\text { duygusal bağlılık düzeylerinin daha az kıdemi olan çalışanlara göre daha yüksek seviyede } \\
\text { olduğu sonucuna ulaşılmıştır. }\end{array}$ \\
\hline
\end{tabular}

Tartışma - Değişen toplum yapısı iş dünyasını ve çalışanların beklentilerini de değiştirmektedir. Dolayısıyla yöneticilerin ve araştırmacıların bu değişimleri dikkate almaları, farklı kuşakların beklentilerini anlayarak doğru motivasyon araçları kullanmaları ve kıdeme bağlı bu duygusal bağlılığın örgüt performansı üzerindeki etkilerini incelemeleri önerilmektedir.

\begin{tabular}{|c|c|}
\hline ARTICLE INFO & ABSTRACT \\
\hline $\begin{array}{l}\text { Keywords: } \\
\text { Paternalistic }\end{array}$ & $\begin{array}{l}\text { Purpose - The purpose of this research is to examine the effect of paternalistic leadership style on } \\
\text { employee performance and emotional commitment. }\end{array}$ \\
\hline Task Performance & Design/methodology/approach - In the research, the sampling method which is not based on \\
\hline Emotional Commitment & $\begin{array}{l}\text { probability and which allows everyone to be included in the sample was preferred. All of the questionnaire } \\
\text { forms, which were accessed online by a simple sampling method and applied to } 200 \text { employees in different }\end{array}$ \\
\hline Received 30 November 2018 & $\begin{array}{l}\text { sectors, were included in the sample. SPSS (Statistical Package Program for Social Science) } 21.0 \text { program } \\
\text { was used to analyze the data. Skewness coefficient was used for the normality test of scale scores. As the }\end{array}$ \\
\hline Revised 28 February 2019 & scale scores were normal distribution, independent two sample t-test was used to compare the scale and \\
\hline Accepted 10 March 2019 & $\begin{array}{l}\text { sub-dimension scores according to gender and birth date (generation); One-way analysis of variance } \\
\text { (ANOVA) was used to compare the time of study in the current company. In the ANOVA test, LSD post } \\
\text { hoc test was used to analyze the difference between the two groups. Pearson correlation analysis for the } \\
\text { relationship between variables; regression analysis was used to analyze the effect of paternalistic }\end{array}$ \\
\hline
\end{tabular}




$\begin{array}{ll}\text { Article Classification: } & \text { leadership style on employee performance and emotional commitment. The confidence interval in the } \\ \text { Research Article } & \text { Findinges was } 95 \% \text {. According to the statistical analysis; It was concluded that the increase in the paternalistic } \\ & \text { leadership perceptions of the employees increased the employee performance and strengthened their } \\ & \text { emotional commitment. However, it has been concluded that the level of emotional commitment is higher } \\ & \text { in employees of generation X than employees of Generation } Y \text { and those who work in the same workplace } \\ & \text { for more than ten years have higher levels of emotional commitment than those with less seniority. } \\ & \text { Discussion - The changing social structure also changes the business world and the expectations of the } \\ & \text { employees. Therefore, it is recommended that managers and researchers take these changes into } \\ & \text { consideration, understand the expectations of different generations, use the right motivation tools and } \\ & \text { examine the effects of this seniority on the organizational performance of seniority. }\end{array}$

\section{Giriş}

Günümüz çalışma yaşamında hızla gelişen dijitalleşme süreci insan unsurunun etkisini sorgulamaya neden olmaktadır. Özellikle insan gücünün yerini pek çok meslekte robotların dolduracağı algısı liderlik stili, çalışma yaşamının geleceği, mesleklerin yapısı ve tüketim alışkanlıkları ile ilgili soruları beraberinde getirmektedir. Ancak liderlik yetkinliklerinin bu değişim sürecinde de en önemli faktörlerden biri olduğu, Dünya Ekonomik Forumu (WEF) tarafından açıklanan 2020'nin en temel on yetkinliği incelendiğinde açıç̧a görülmektedir. İnsan yönetimi ve duygusal zeka yetkinlikleri her dönemde yerlerini korumaktadır. Liderden beklenen, yöneticilik becerilerinin yanı sıra insanların duygularını anlama, empati kurabilme ve vizyona yönelik hedeflere ulaşmak için çalışanların motivasyonunu her koşulda yüksek tutabilmesidir.

Babacan liderlik tarzı, kişiselleştirilmiş bir atmosferde güçlü bir disiplin, otorite ve babacan yetin bir araya geldiği bir liderlik stili olarak tanımlanmaktadır ve otoriterlik, yardımseverlik ve ahlak olmak üzere üç boyuttan oluşmaktadır. Liderin bir otorite olarak varlığını hissettirmesi önemlidir ancak bu otoriteyi başkaları ile kurduğu işbirliği çerçevesinde yürütmektedir. Dolayısıyla içinde bulunulan toplumun kültürü çalışanların beklentilerini etkilemekte, bu beklentiler de liderlik tarzının belirleyicisi olmakta ve performans düzeyini etkilemektedir. Bu bağlamda babacan liderlik tarzının çalışan görev performansı ve duygusal bağlılık üzerindeki etkisini analiz etmek amacıyla araştırma yapılmıştır. Araştırmada ilk olarak kavramsal çerçeveyi oluşturan babacan liderlik, çalışan görev performansı ve duygusal bağlılık kavramları açıklanmıştır. Daha sonra araştırma modeline ait hipotez ve değişkenler arası ilişkiler analiz edilmiş ve elde edilen bulgular sonuç kısmında değerlendirilmiştir.

\section{Kavramsal Çerçeve}

\subsection{Babacan Liderlik}

Liderlik, bir bireyin belirli şartlar altında belirli kişilerin ve grupların amaçlarını gerçekleştirmek üzere diğerlerini yönlendirmesidir (Akdemir, 2018: 107-108). İyi liderler insanları çok farklı şekillerde motive ederler. İlk olarak, çalışanları kararlara dahil ederler ve kontrol duygularını geliştirirler. Daha sonra onlara geribildirim vererek, koçluk yaparak ve bir rol model olarak özsaygılarının gelişimine yardımcı olurlar ve son olarak, çalışanların başarılarını ödüllendirirler. Belirtilen bu davranışların hem örgütün performansını hem de çalışanların bağlılığını olumlu yönde etkilediğine yönelik pek çok araştırma bulgusu mevcuttur (Podsakoff vd. 1996; Lim ve Ployhart, 2004; Awan ve Mahmood, 2010; Walumbwa vd. 2008; Chen vd. 2014; Chan ve Mak, 2012).

Babacan liderlik ile ilgili çalışmalarının başlangıcı, Silin'in 1976 yılında Tayvan'daki işletme sahibi ve yöneticilerin liderlik anlayışları ve davranış stillerinin Batı ülkelerindeki yöneticilerinkinden oldukça farklı olduğunu tespit eden çalışması ile başlamıştır. Bu çalışma Tayvan'daki yöneticilerin didaktik ve ahlaki liderlik, merkezi otorite, astlarıyla mesafeli durma gibi davranışlar sergilediğini ortaya koymuştur (Silin, 1976). Westwood'un 1997 yılındaki çalışmasında, didaktik liderlik, belirsiz niyetler, saygınlık oluşturma, üstünlügünü koruma, politik manipülasyon patronluk ve sosyal mesafe gibi bileşenlerden oluşan babacan liderlik modelini öne sürmüştür (Westwood, 1997:445-480). Babacan lider, görev aldıkları kurumları ve çalışma arkadaşlarını aileleri gibi benimseyerek çalışırlar. (Köksal, 2011:101-122). Kişiselleştirilmiş bir atmosferde güçlü bir disiplin, otorite ve babacan niyetin bir araya geldiği bir liderlik stili olarak tanımlanmaktadır ve otoriterlik, yardımseverlik ve ahlak olmak üzere üç boyuttan oluşmaktadır (Farh ve Cheng, 2000:84-127; Cheng vd., 2004:89-117). Bu yetkinlikler çerçevesinde bakıldığında babacan bir lider 
güçlü bir duygusal zeka yetkinliğine sahip olmalıdır. Türk kültüründe liderin özelliklerini açıklayan ve global alanda yürütülen bir araştırmada ise; otokrasi, ikna etme, statü merakı ve işbirliği sağlama özelliklerinin ortalamasının aynı araştırmanın yapıldığı diğer ülkelere oranla oldukça yüksek olduğu sonucuna ulaşılmıştır (Baltaş, 2015:37). Otoriterlik, yöneticinin izleyicileri üzerinde kesin bir güce sahip olduğu ve tüm kararları kendisinin vererek izleyicilerin eylemlerini kontrol etmesini ifade etmektedir. Yardımseverlik, liderin izleyicilerinin özel hayatları ve sağlıkları ile ilgilenmesi anlamını taşımaktadır. Ahlak ise, liderin yüksek ahlaki değerler, vatandaşlık davranışları ve dürüstlük gibi özellikleri sergileyerek izleyicileri için mükemmel bir rol model olmayı içermektedir (Peng vd., 2001:95-110). Babacan liderlik, yöneticinin bir ebeveyn gibi çocuklarına yardımseverlikle müdahale ettiği bir sistem, ilke ya da bir yönetim uygulaması olarak görülmektedir (Afsar ve Rehman, 2015:329-353).

Belli bir kültüre yönelik özelliklerin liderlik stillerinin belirleyicisi olabildiği ve çeşitli toplumların kültürel değerlerinin ortaya çıkardığı liderlik stillerinin de birbirinden oldukça farklı olduğu görülmüştür (Shahin ve Wright, 2004:499-511). Martinez'in (2003) çalışmasında, çalışanların sosyal hiyerarşi saygısı, aile ilişkilerine benzer bir örgüt iklimi, kişisel ilişkilere değer verilmesi, esneklik ve güven gibi unsurların babacan liderliğe uygun bir ortam hazırladığı belirlenmiştir. Bir diğer öncül olarak ise, lider-üye etkileşimi ön plana çıkmıştır (Ansari, Ahmad ve Aafaqi, 2004:109-138; Pellegrini ve Scandura, 2006:264-279). Babacan liderliğin ilişkili olduğu diğer kavramlar arasında kariyer gelişimi (Uhl-Bien vd., 1990:414-430), iş tatmini, otonomi, güçlendirme (Aycan vd., 2000:199-221) ve örgütsel bağlılık (Pellegrini vd., 2006:264-279) bulunmaktadır. Psikolojik olarak da çalışanları güçlendirme ve örgütsel bağlılık göz önüne alındığında babacan liderler, çalışanlarından beklentilerini açıkça tanımlayarak ve grup üyeleriyle etkileşim içinde bulunarak onları Türkiye' de babacan liderlik ile ilgili yapılan çalışmalara bakıldığında; babacan liderlik ile psikolojik yıldırma arasında ters yönde ilişkiler olduğuna ilişkin bulgular vardır. Aynı şekilde, babacan liderliğin çalışanların yöneticilerinden ve işin doğasından duydukları doyumun bir öncülü olduğu belirlenmiştir (Soylu, 2011:217231; Cerit, 2012:35-56). Babacan liderlik ile çalışanların yaratıcı katılım algıları arasında olumlu yönde ilişkiler bulunduğu gözlemlenmiştir (Kurt, 2013:321-330). Bir başka deyişle, yöneticilerin babacan liderlik sergilediği durumda işe katılımlarının arttı̆̆ı söylenebilir. Babacan liderlik davranışları, örgütsel vatandaşlık duygusunu pozitif yönlü etkilerken, çalışanların kurumsal aidiyet ve özdeşleşme duygularını da arttırırlar (Rehman ve Afsar, 2012:148-159; Göncü, Aslı ve Johnson, 2014; Şendoğdu ve Erdirençelebi, 2014:253-274; Mete ve Serin, 2015:147-159). Bununla birlikte, babacan liderlik örgütsel bağlllı̆̆1 olumlu yönde etkilemektedir (Erben ve Güneşer, 2008:955-968).

\section{2. Çalışan Görev Performansı}

Performans, çalışanın kendisinden beklenen görevleri yerine getirmesi ve hatta beklentilerin ötesine geçmesidir (Whitmore, 2015:100). Bireysel performans, örgütsel amaçlara ulaşabilmek için bireyin kullandığ1 yetkinlikler olarak ifade edilebilir. Bu yetkinlikler işe yönelik ve işe yönelik olmayan davranışları içermektedir. İşe yönelik davranışlar doğrudan hedef odaklı, somut çıtılara ulaşmaya yönelik teknik becerilerken, işe yönelik olmayan davranışlar ise ekip çalışması, müşteri odaklılık, yardımsever olma, örgüt kültürünü sahiplenme ve bireysel disiplin gibi daha soyut yetkinlikleri belirtmektedir (Barutçugil, 2015:47). Araştırmalarda örgüt içerisinde performansı oluşturan üç tür davranış olduğu savunulmaktadır. Bunlar; görev performansı, örgüte vatandaşlık ve örgüte zarar verici davranıştır (Robbins ve Judge, 2012:565). Görev performansı; bir çalışanın kendisine verilen hedeflere ne derece ulaşttğı düzeyidir (Luecke, 2015:101). Örgütsel vatandaşlık; bireyin kendi sorumluluklarının ötesinde ve iş tanımının dışında kendisinden beklenmeyen ancak örgütün başarısına katkı sağlayan gönüllü çabalarının ifadesidir (Organ, 1988). Örgüte zarar verici davranışlar ise; örgütün malına zarar verme, iş arkadaşlarına karşı saldırgan davranma ve devamsızlık başta olmak üzere hem bireysel hem de örgütsel performansı olumsuz etkileyen her türlü harekettir (Robbins ve Judge, 2012:565).

Performans ile ilgili tanımlar ve performans düzeyini sergileyen davranışların yanı sıra performansın nasıl değerlendirileceği ve performansın yönetimi konuları da literatürde geniş yer bulmaktadır. Çünkü nihai hedef performansın sürekli olarak iyileştirilmesi ve hedeflenen verimlilik düzeyine ulaşılmasıdır. Performans değerlendirme performans yönetim sürecinin kritik bir parçası olarak kabul edilir (Çetin, vd. 2015:154; Paauwe ve Farndale, 2017:80). Etkili bir performans değerlendirme süreci; iş standartlarının belirlenmesi, çalışanların bu standartlara göre mevcut performanslarının ölçülmesi ve geribildirim verilmesi, eğitim ve gelişim ihtiyaçlarının belirlenmesi ve ödüllendirme faaliyetlerini kapsar (Briscoe ve Claus, 
2008:15). Buna rağmen günümüzün performans değerlendirme sistemleri halen beklentileri karşılamamaktadır. Watson Wyatt tarafından yapılan bir araştırmada; çalışanların yalnızca yüzde otuzunun örgütlerindeki performans yönetim sistemini etkin kabul ettikleri ve yüzde kırktan daha azının performans hedeflerinin belirgin olduğunu ifade ettikleri sonucuna ulaşılmıştır (Pulakos, 2007:293). Performans yönetimini etkileyen başlıca faktörler ise; içinde bulunulan toplumun kültürü, örgüt içindeki liderlik stili, örgütün kültürü, iletişim şeklidir (Brewster ve Mayrhofer, 2012:375). İşgörenlerin görev performansını etkileyen diğer faktörler kişilik yapısı, iş tatmini, motivasyon ve stres şeklinde ifade edilebilir (Akar, 2018:57 ve Yelboğa, 2006:208).

Bir performans yönetim sistemi geliştirilirken basit ve anlaşılır olmasına özen gösterilmelidir. Özellikle örgüt içerisindeki roller belirgin olmalı ve hedefler bu rollere uygun olarak belirlenmelidir. Ancak performansın kesin bir şekilde ölçülmesinin zorluğu da göz önünde bulundurulmalıdır. Her örgüt mutlaka kendine özgü bir değerlendirme şekli belirlemektedir. En basit haliyle finansal bir değerlendirme yapmaktadır. Bu değerlendirmelerde bile mutlaka görülmeyen veya sonuçları dolaylı olarak etkileyen faktörler olduğu bilinmektedir. Coens ve Jenkins (2002) aşağıdaki ifadelerinde, performansı değerlendirme ve yönetmenin zorluğunu vurgulamaktadırlar (Armstrong, 2016:156):

"İ̧̧ hayatımız boyunca çoğumuz performans değerlemesiyle uğraştır. Ne kadar çok yeniden tasarlasak, yöneticileri ne kadar çok yeniden eğitsek veya konuyu yeniden adlandırsak da önemli değil, asla tam olmaz. Yöneticilerin, işi fazla ciddiye almayarak sürüncemede bıraktıklarını veya işi sadece üstünkörü yaptıklarını her defasında görüyoruz. Bu işi gönülden, ellerinden gelenin en iyisini yapmaya gayret ederek yapan yöneticiler ise çoğunlukla hayal kurıklı̆̆ ile karşılaşıyor". Bu değerlendirmeden de anlaşılacağı gibi, sistemin çok iyi kurgulanması başarılı olması için yeterli olmamaktadır. Özellikle duygusal faktörlerin ön planda olduğu, yöneticilerin çalışanlarla karşı karşıya gelmekten ve onlarla yanlış bir iletişim kurmaktan kaçındıkları geribildirim süreci performans yönetiminin en önemli unsurudur. Çünkü olumlu ya da olumsuz her ifade çalışanın zihninde yorumlanmakta ve bir sonraki adım bu yoruma göre atılmaktadır. Dolayısıyla yöneticinin liderlik davranışı, çalışana yönelik tutumu, değer algısı ve işe yönelik beklentiler çalışan performansını direkt etkilemektedir.

\subsection{Duygusal Bağlılık}

Bağlılık kişinin bir nesne, düşünce ya da kişiye inanmayı ifade eden bir kavramdır (Esty, Winston, 2006). İnsanlar yaşadıkları yere, şehre ülkeye, sevdikleri kişilere ve çalıştıkları kuruma karşı bağlılık duygusu hissedebilir. Günümüzün rekabet odaklı hızla değişen iş dünyasında bağlı çalışanlara sahip işletmeler daha yüksek performans göstermektedirler (Myers, 2005). Örgütsel bağlılık, çalışanın görev aldığı örgütte çalışmaya devam etmek yönünde duyduğu içten gelen güçlü bir istektir (Luthans, 1995:130). Örgütsel bağlılık çalışanı görev aldığı kurumla bir örümcek ağı gibi görünmez ama kuvvetli şekilde bağlayan bir güçtür (Casson, 2006:43).

Duygusal bağlılık çalışanın görev aldığı örgüte karşı duyduğu duygusal bağın göstergesidir (Kaya, Selçuk, 2007:179). Duygusal bağlılık, çalışanın sahip olduğu işe ne kadar odaklanıp sevdiğini gösteren bir kavramdır (Kanten, Kanten, 2016:202). İşgörenin çalıştığı örgüte olan sadakatini, misyon ve vizyona adanmışlığının bir göstergesidir (Porter vd., 1974:604). Duygusal bağllık çalışanın kendi kimliğiyle örgütü özdeşleştirmesini sağlayan güçlü bir histir (Pieper vd., 2018: 1163).

Duygusal bağlılığa sahip çalışanların örgütlerinde kalma nedeni maddi faktörler ve ödülller değil örgütleriyle aralarındaki güçlü duygusal bağdır (Balay, 2000; Pieper vd., 2018: 1163). İşgörenin çalışttğg örgütle kendini özdeşleştirmesi kökenli duygusal bağlılığın oluşması için çalışanın örgütün amaç ve hedeflerini sahiplenip içselleştirmesi, örgüt başarısı için içsel bir motivasyonla çalışması ve örgütte çalışmak için güçlü bir istek duyması gereklidir (Yorulmaz, 2018: 870). Duygusal bağlılığı etkileyen birçok farklı etken vardır (Eser, 2007: 32-33):

- Kişinin karakteri ve kişisel özellikleri,

- Yapılan işi menşei ve özellikleri,

- Kişinin deneyimi,

- İşgörene çalıştığı kurumda değer verilip, gelişimine imkan tanınması,

- Örgütsel adaletin var olması, 
- İş güvencesi olması,

- İşgörenin kararlara katılımının sağlanması,

- Örgüt içi etkin iletişimin varlığı,

- Örgütte güven ortamının var olması,

- Yönetim ve çalışanlar tarafından paylaşılan ortak değerlerin varlığı.

İşgörenler çalıştıkları kurumları seçmekte fakat yöneticilerinden ayrılmaktadırlar yani işe başlarken işletme kararı etkilerken ayrılma kararına çoğu zaman birlikte çalışılan yönetici sebep olmaktadır. İşte bu noktada çalışanın görev aldığ kuruma ve yöneticisine olan duygusal bağl1lı̆ı kararı etkileyen en önemli etkenlerden biri konumundadır (Mullins,2016:586).

Duygusal bağlılık diğer bağlılık türlerine kıyasla çalışanının davranışını ve performansını etkileyen en önemli bağl1lık türüdür (Grant vd., 2008; Meyer vd., 2002). Duygusal bağlllik örgütün performansı ve başarısını etkileyen birçok olumlu etkisi vardır:

- Duygusal bağlılıkları yüksek çalışanların, mesleklerini yapma istekleri daha yüksektir (Tanrıverdi, Koçaslan, 2018:250).

- Duygusal bağlılıkları yüksek olan çalışanlar işi ve örgütün hedeflerini sanki kendi işyerleri gibi benimseyip önemserler (Poon, 2010).

- Duygusal bağlllık örgütsel vatandaşlık davranışını arttırırken, işten ayrılma oranını azaltıcı bir etkiye sahiptir (Meyer vd., 2002).

- Duygusal bağlılıkları yüksek olan çalışanların devamsızlık oranları daha düşüktür (Harrison vd., 2006).

- Duygusal bağlılıkları yüksek olan çalışanlar diğerlerine göre daha verimli ve yüksek performanslı çalışırlar (Zatzick vd., 2015: 878).

- Duygusal bağlılık çalışanların adanmışlık ve örgütle özdeşleşmelerini olumlu etkiler (May vd., 2004).

- Duygusal bağlılık çalışan memnuniyeti ve tatminini olumlu etkiler (Poon, 2013:1149).

Duygusal bağlılık çalışan ve örgüt performansını en fazla pozitif yönde etkileyen bağlılık çeşididir. İlgili alan yazında bu görüşü destekleyen birçok araştırma (Akdemir, Çalış, 2016; Arsezen vd., 2015; Ellinger vd., 2013; Arshadi, Hayavi, 2013; A ğca, Ertan, 2008) yer almaktadır.

\section{Araştırma Modeli ve Hipotezler}

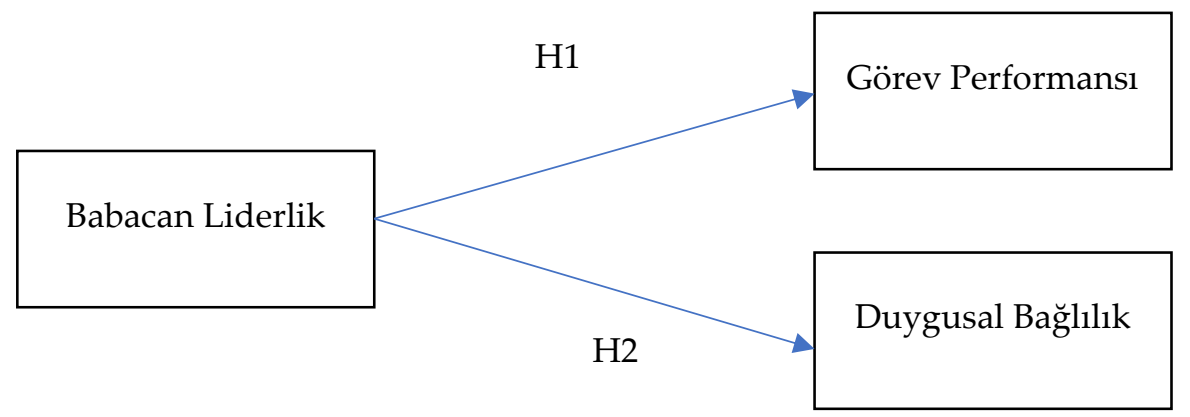

H1: Babacan liderlik algısının görev performansı üzerinde anlamlı etkisi vardır.

$\mathrm{H}_{2}$ : Babacan liderlik algısının duygusal bağlılık üzerinde anlamlı etkisi vardır.

\subsection{Veri Toplama Aracı}

Araştırmada veri toplama aracı olarak dört bölümden oluşan anket formu kullanılmıştır. Veri toplama aracının birinci bölümünde katılımcıların cinsiyet, yaş ve mevcut şirketteki çalışma süresi demografik bilgilerinden oluşan bilgi formu kullanılmıştır. İkinci bölümde Aycan (2006) tarafından geliştirilen Babacan Liderlik Ölçeği kullanılmıştır. Ölçekte tek boyut altında 10 madde yer almaktadır. Cevap seçenekleri 5'li likert (1-kesinlikle katılmıyorum, 5-kesinlikle katılıyorum) şeklindedir. Bu çalışmada ölçeğin Cronbach 
Alpha katsayısı 0,94 olarak hesaplanmıştır. Üçüncü bölümde Goodman ve Syvantek (1999) (Görev Performansı) ve Jawahar ve Carr (2007) (Bağlamsal Performans) geliştirilen ve Bağcı (2014) tarafından Türkçe'ye uyarlanıp güvenirlik ve geçerlik analizleri yapılan Çalışan Performansı Ölçeği kullanılmıştır. Ölçek 17 madde ve 2 boyuttan (görev performansı, bağlamsal performans) oluşmaktadır. Cevap seçenekleri 5’li likert (1-kesinlikle katılmıyorum, 5-kesinlikle katılıyorum) şeklindedir. Boyutlar için puanlar ayrı ayrı hesaplanmakta olup yüksek puan performans algısının yüksekliğini ifade etmektedir. Bu çalışmada ölçeğin Cronbach Alpha katsayısı 0,91; alt boyutların Cronbach Alpha katsayıları 0,90 ve 0,84 olarak hesaplanmıştır. Dördüncü bölümde Meyer vd. (1993) tarafından geliştirilen, 18 sorudan ve üç boyuttan (duygusal, devamlılık ve normatif bağlılık) oluşan "Örgütsel Bağlılık Ölçeği"nden duygusal bağlllığı ölçen 6 soru kullanılmıştır. Ölçek Köroğlu (2018) tarafından yapılan çalışmada da kullanılmıştır. Cevap seçenekleri 5’li likert (1-kesinlikle katılmıyorum, 5-kesinlikle katılıyorum) şeklindedir. Yüksek puan örgüte yönelik duyusal bağlılığın yüksek olduğunu ifade etmektedir. Araştırmada ölçeğe ait Cronbach Alpha katsayısı 0,90 olarak hesaplanmıştır.

\subsection{Verilerin Analizi}

Verilerin analizinde SPSS (Statistical Package Program for Social Science) 21.0 programı kullanılmıştır. Katılımcıların demografik bilgileri frekans ve yüzde tablosu olarak gösterilmiştir. Çarpıklık (Skewness) katsayısı ölçek puanlarının normallik sınaması için kullanılmıştır. Sürekli bir değişkenden elde edilen puanların normal dağılım özelliğinde kullanılan çarpıklık katsayısının (Skewness) \pm 1 sınırları içinde kalması puanların normal dağılımdan önemli bir sapma göstermediği şeklinde değerlendirilebilir (Büyüköztürk, 2011:40). Yapılan normallik sınamasında ölçek puanlarının normal dağılım gösterdiği tespit edildiğinden ölçek ve alt boyut puanlarının cinsiyet ve doğum tarihine (kuşak) göre karşılaştırılmasında bağımsız iki örneklem $t$ testinden; mevcut şirketteki çalışma süresine göre karşılaştırılmasında tek yönlü varyans analizinden (ANOVA) yararlanılmıştır. ANOVA testinde anlamlı farklılık görüldüğünde farkın hangi iki grup arasında olduğunu belirlemek amacıyla LSD post hoc testinden yararlanılmıştır. Değişkenler arasındaki ilişki analizi için Pearson korelasyon analizinden; babacan liderlik tarzının çalışan performansı ve duygusal bağlllık üzerine etkisini analiz etmek için regresyon analizi kullanılmıştır. Analizler sonucunda güven aralığ $\% 95(\mathrm{p}<0,05)$ olarak tespit edilmiştir.

\subsection{Bulgular}

\subsubsection{Betimsel Bulgular}

Tablo 1'de katılımcıların demografik özelliklerine göre dağılımı yer almaktadır.

Tablo 1. Katılımcıların Demografik Özelliklerine Göre Dağılımı

\begin{tabular}{lccc}
\hline $\begin{array}{l}\text { Demografik } \\
\text { Değişken }\end{array}$ & Gruplar & n & \% \\
\hline \multirow{2}{*}{ Cinsiyet } & Kadın & 109 & 54,5 \\
& Erkek & 91 & 45,5 \\
\hline Doğum tarihi & X kuşağı (1965-1979) & 47 & 23,5 \\
(kuşağı) & Y kuşağı (1980-1999) & 153 & 76,5 \\
\hline & 1 yıldan az & 32 & 16,0 \\
Mevcut şirketteki & $1-3$ yıl & 53 & 26,5 \\
çalışma süresi & $4-6$ yıl & 54 & 27,0 \\
& $7-9$ yıl & 22 & 11,0 \\
& 10 yıl ve üstü & 39 & 19,5 \\
\hline
\end{tabular}

Araştırmada olasılığa dayalı olmayan ve herkesi örneğe dahil edilebilme imkanı veren kolayda örnekleme yöntemi tercih edilmiştir (Altunışık vd., 2012: 142). Kolayda örnekleme yöntemiyle çevrimiçi olarak araştırmaya katılan farklı sektörlerde görev alan 200 çalışanın \%54,5'i kadın, \%45,5'i erkektir. Katılımcıların \%23,5'i X kuşağı (1965-1979) ve \%76,5'i Y kuşağıdır (1980-1999). Katılımcıların \%16'sının mevcut işletmedeki çalışma süresi 1 yıl ve daha az, \%26,5'inin 1-3 yıl, \%27'sinin 4-6 yll, \%11'inin 7-9 yıl, \%19,5'inin 10 yll ve üstüdür.

Tablo 2'de ölçek ve alt boyutlarına ait betimsel istatistikler bulunmaktadır. 
Z. Hatipoğlu - G. Akduman - B. Demir 11/1 (2019) 279-292

Tablo 2. Ölçeklere Ait Betimsel İstatistikler

\begin{tabular}{llccc}
\hline Ölçek ve Alt Boyut & $\mathbf{n}$ & $\overline{\mathbf{X}}$ & SS & Skewness \\
\hline BABACAN LİDERLIKK & 200 & 3,12 & 1,02 & $-0,22$ \\
\hline Görev Performansı & 200 & 4,32 & 0,53 & $-0,60$ \\
Bağlamsal Performans & 200 & 4,10 & 0,61 & $-0,21$ \\
ÇALIŞAN PERFORMANSI & 200 & 4,23 & 0,51 & $-0,31$ \\
\hline DUYGUSAL BAĞLILIK & 200 & 3,28 & 0,95 & $-0,39$ \\
\hline
\end{tabular}

Katılımcıların babacan liderlik algı puanları $(3,12 \pm 1,02)$ "orta" düzeyde tespit edilmiştir(Tablo 2). Görev performansı $(4,32 \pm 0,53)$, bağlamsal performans $(4,10 \pm 0,61)$ alt boyutları ve performans ölçeği toplam $(4,23 \pm 0,51)$ puanları "yüksek" düzeyde tespit edilmiştir (Tablo 2). Duygusal bağlılık puanları $(3,28 \pm 0,95)$ "orta" düzeyde tespit edilmiştir (Tablo 2).

\subsubsection{Demografik Özelliklere Göre Ölçek Puanlarının Karşılaştırılması Bulguları}

Tablo 3'te ölçek puanlarının cinsiyete göre t testi sonuçları yer almaktadır.

Tablo 3. Ölçek Puanlarının Cinsiyete Göre t Testi Sonuçları

\begin{tabular}{|c|c|c|c|c|c|c|}
\hline Ölçek ve Alt Boyutlar & Cinsiyet & $\mathbf{n}$ & $\overline{\mathbf{x}}$ & SS & $t$ & p \\
\hline BABACAN LİDERLİK & Kadın & 109 & 3,03 & 0,99 & \multirow{2}{*}{$-1,27$} & \multirow{2}{*}{0,205} \\
\hline ALGISI & Erkek & 91 & 3,22 & 1,04 & & \\
\hline \multirow{2}{*}{ Görev Performansı } & Kadın & 109 & 4,34 & 0,50 & \multirow{2}{*}{0,51} & \multirow{2}{*}{0,612} \\
\hline & Erkek & 91 & 4,30 & 0,57 & & \\
\hline \multirow{2}{*}{ Bağlamsal Performans } & Kadın & 109 & 4,12 & 0,56 & \multirow{2}{*}{0,66} & \multirow{2}{*}{0,512} \\
\hline & Erkek & 91 & 4,07 & 0,67 & & \\
\hline \multirow{2}{*}{$\begin{array}{l}\text { ÇALIŞAN } \\
\text { PERFORMANSI }\end{array}$} & Kadın & 109 & 4,25 & 0,47 & \multirow{2}{*}{0,63} & \multirow{2}{*}{0,528} \\
\hline & Erkek & 91 & 4,20 & 0,57 & & \\
\hline \multirow{2}{*}{ DUYGUSAL BAĞLILIK } & Kadın & 109 & 3,26 & 0,98 & \multirow{2}{*}{$-0,21$} & \multirow{2}{*}{0,833} \\
\hline & Erkek & 91 & 3,29 & 0,92 & & \\
\hline
\end{tabular}

Babacan liderlik algısı puanlarının cinsiyete göre anlamlı farklılık göstermediği ( $>>0,05)$ (Tablo 3), çalışan performansı ölçek ve alt boyut puanlarının cinsiyete göre anlamlı farklılık göstermediği $(p>0,05)$ bulgusuna ulaşılmıştır (Tablo 3). Duygusal bağlılık ölçek puanları da cinsiyete göre anlamlı farklılık göstermemektedir ( $\mathrm{p}>0,05)$ (Tablo 3).

Tablo 4'te ölçek puanlarının doğum tarihine (kuşağa) göre karşılaştırmasına ait bağımsız iki örneklem $t$ testi sonuçlarına yer verilmiştir.

Tablo 4. Ölçek Puanlarının Doğum Tarihine (Kuşağa) Göre t Testi Sonuçları

\begin{tabular}{|c|c|c|c|c|c|c|}
\hline Ölçek ve Alt Boyutlar & $\begin{array}{l}\text { Doğum Tarihi } \\
\text { (Kuşak) }\end{array}$ & $\mathbf{n}$ & $\overline{\mathbf{x}}$ & SS & $t$ & $\mathrm{p}$ \\
\hline \multirow{2}{*}{$\begin{array}{l}\text { BABACAN LİDERLİK } \\
\text { ALGISI }\end{array}$} & X kuşağ1 & 47 & 3,16 & 1,02 & \multirow{2}{*}{0,35} & \multirow{2}{*}{0,728} \\
\hline & Y kuşağ1 & 153 & 3,10 & 1,02 & & \\
\hline \multirow{2}{*}{ Görev Performansı } & X kuşağ 1 & 47 & 4,31 & 0,59 & \multirow{2}{*}{$-0,09$} & \multirow{2}{*}{0,929} \\
\hline & Y kuşağ1 & 153 & 4,32 & 0,52 & & \\
\hline \multirow{2}{*}{ Bağlamsal Performans } & X kuşağ1 & 47 & 4,17 & 0,64 & \multirow{2}{*}{0,88} & \multirow{2}{*}{0,380} \\
\hline & Y kuşağ1 & 153 & 4,08 & 0,60 & & \\
\hline \multirow{2}{*}{ ÇALIŞAN PERFORMANSI } & X kuşağ1 & 47 & 4,25 & 0,57 & \multirow{2}{*}{0,38} & \multirow{2}{*}{0,707} \\
\hline & Y kuşağ1 & 153 & 4,22 & 0,50 & & \\
\hline \multirow{2}{*}{ DUYGUSAL BAĞLILIK } & X kuşağ1 & 47 & 3,55 & 1,10 & \multirow{2}{*}{2,27} & \multirow{2}{*}{0,024} \\
\hline & Y kuşağ1 & 153 & 3,19 & 0,88 & & \\
\hline
\end{tabular}


Z. Hatipoğlu - G. Akduman - B. Demir 11/1 (2019) 279-292

Babacan liderlik algısı puanları doğum tarihine (kuşağa) göre anlamlı farklılık göstermemekte $(p>0,05)$ (Tablo 4), çalışan performansı ölçek ve alt boyut puanları doğum tarihine (kuşağa) göre anlamlı farklılık göstermemektedir ( $>00,05)$ (Tablo 4). Duygusal bağlllık ölçek puanların doğum tarihine (kuşağa) göre anlamlı farklılık göstermemektedir ( $t=2,27 ; p<0,05)$. X kuşağı (1965-1979) çalışanların duygusal bağl1lık puanları, Y kuşağı (1980-1999) çalışanların puanlarından anlamlı düzeyde daha yüksektir (Tablo 4).

Tablo 5'te ölçek puanlarının mevcut şirketteki çalışma süresine göre karşılaştırmasına ait tek yönlü varyans analizi (ANOVA) sonuçları yer almaktadır.

Tablo 5. Ölçek Puanlarının Mevcut Şirketteki Çalışma Süresine Göre ANOVA Testi Sonuçları

\begin{tabular}{|c|c|c|c|c|c|c|c|}
\hline $\begin{array}{l}\text { Ölçek Alt } \\
\text { Boyutlar }\end{array}$ & $\begin{array}{c}\text { Şirketteki } \\
\text { Çalışma Süresi }\end{array}$ & $\mathbf{n}$ & $\overline{\mathbf{X}}$ & SS & $\mathbf{F}$ & $p$ & $\begin{array}{c}\text { Anlamlı } \\
\text { Fark }\end{array}$ \\
\hline \multirow{5}{*}{$\begin{array}{l}\text { BABACAN } \\
\text { LİDERLİK } \\
\text { ALGISI }\end{array}$} & A-1 yıldan az & 32 & 3,41 & 1,01 & \multirow{5}{*}{1,37} & \multirow{5}{*}{0,247} & \\
\hline & B- $1-3$ y1l & 53 & 3,07 & 1,06 & & & \\
\hline & C- 4-6 y1l & 54 & 3,19 & 0,93 & & & \\
\hline & D- 7-9 yıl & 22 & 2,82 & 1,17 & & & \\
\hline & E-10 yıl ve üstü & 39 & 3,00 & 0,97 & & & \\
\hline \multirow{5}{*}{$\begin{array}{l}\text { Görev } \\
\text { Performansı }\end{array}$} & A-1 yıldan az & 32 & 4,26 & 0,60 & \multirow{5}{*}{1,02} & \multirow{5}{*}{0,396} & \\
\hline & B- 1-3 yıl & 53 & 4,33 & 0,50 & & & \\
\hline & C- 4-6 yil & 54 & 4,23 & 0,50 & & & \\
\hline & D- 7-9 yil & 22 & 4,43 & 0,58 & & & \\
\hline & E-10 yıl ve üstü & 39 & 4,42 & 0,54 & & & \\
\hline \multirow{5}{*}{$\begin{array}{l}\text { Bağlamsal } \\
\text { Performans }\end{array}$} & A-1 yıldan az & 32 & 4,08 & 0,56 & \multirow{5}{*}{0,95} & \multirow{5}{*}{0,434} & \\
\hline & B- 1-3 yil & 53 & 4,14 & 0,59 & & & \\
\hline & C- $4-6$ yil & 54 & 4,00 & 0,65 & & & \\
\hline & D- 7-9 yil & 22 & 4,03 & 0,63 & & & \\
\hline & E-10 yıl ve üstü & 39 & 4,23 & 0,62 & & & \\
\hline \multirow{5}{*}{$\begin{array}{l}\text { ÇALIŞAN } \\
\text { PERFORMANSI }\end{array}$} & A-1 yıldan az & 32 & 4,19 & 0,54 & \multirow{5}{*}{1,02} & \multirow{5}{*}{0,397} & \\
\hline & B- 1-3 y1l & 53 & 4,25 & 0,47 & & & \\
\hline & C- 4-6 yil & 54 & 4,14 & 0,51 & & & \\
\hline & D- 7-9 yil & 22 & 4,26 & 0,51 & & & \\
\hline & E-10 yıl ve üstü & 39 & 4,34 & 0,55 & & & \\
\hline \multirow{5}{*}{$\begin{array}{l}\text { DUYGUSAL } \\
\text { BAĞLILIK }\end{array}$} & A-1 yıldan az & 32 & 3,28 & 0,77 & \multirow{5}{*}{3,93} & \multirow{5}{*}{0,004} & $\mathrm{E}>\mathrm{A}, \mathrm{B}, \mathrm{C}, \mathrm{D}$ \\
\hline & B- 1-3 y1l & 53 & 3,07 & 1,01 & & & \\
\hline & C- 4-6 yil & 54 & 3,35 & 0,84 & & & \\
\hline & D- 7-9 yıl & 22 & 2,86 & 0,99 & & & \\
\hline & E-10 y1l ve üstü & 39 & 3,70 & 0,97 & & & \\
\hline
\end{tabular}

Babacan liderlik algısı puanları mevcut şirketteki çalışma süresine göre anlamlı farklılık göstermemektedir $(p>0,05)$ (Tablo 5). Çalışan performansı ölçek ve alt boyut puanlarının mevcut şirketteki çalışma süresine göre anlamlı farklılık göstermediği ( $p>0,05)$ tespit edilmiştir (Tablo 5). Duygusal bağlllık ölçek puanlarının mevcut şirketteki çalışma süresine göre anlamlı farklılık gösterdiği tespit edilmiştir ( $F=3,93 ; p<0,05)$. Farkın hangi gruplar arasında olduğunu belirlemek amaciyla yapılan LSD post hoc testi sonuçlarına göre mevcut şirketteki çalışma süresi 10 yıl ve üstü olan çalışanların duygusal bağlılık puanları, mevcut şirketteki çalışma süresi 9 yıl ve daha az olan çalışanların puanlarından anlamlı düzeyde daha yüksektir (Tablo 5).

\subsubsection{Değişkenler Arası İlişkiye Ait Bulgular}

Babacan liderlik algısı, çalışan performansı ve duygusal bağlılık arasındaki ilişkiyi gösteren Pearson korelasyon analizi sonuçları Tablo 6'da a yer almaktadır. 
Z. Hatipoğlu - G. Akduman - B. Demir 11/1 (2019) 279-292

Tablo 6. Değişkenler Arasındaki Korelasyon Analizi Sonuçları

\begin{tabular}{lcccc}
\hline \multicolumn{1}{c}{ Değişkenler } & $\mathbf{2}$ & $\mathbf{3}$ & $\mathbf{4}$ & $\mathbf{5}$ \\
\hline 1-BABACAN LIDERLİK ALGISI & 0,04 & $0,20^{* *}$ & 0,12 & $0,39^{* *}$ \\
\hline 2-Görev Performansı & 1 & $0,64^{* *}$ & $0,93^{* *}$ & $0,24^{* *}$ \\
3-Bağlamsal Performans & & 1 & $0,88^{* *}$ & $0,46^{* *}$ \\
4-ÇALIŞAN PERFORMANSI & & & 1 & $0,38^{* *}$ \\
\hline 5-DUYGUSAL BAĞLILIK & & & & 1 \\
\hline${ }^{*}<0,05^{* *} \mathrm{p}<0,01$ & & &
\end{tabular}

Babacan liderlik algısı ile görev performansı arasında pozitif yönlü ve anlamlı ilişki tespit edilmiştir ( $\mathrm{r}=0,20$; $\mathrm{p}<0,05$ ). Babacan liderlik algısı yüksek olan çalışanların görev performansı da yüksektir (Tablo 6). Babacan liderlik algısı ile duygusal bağlılık arasında pozitif yönlü ve anlamlı ilişki tespit edilmiştir $(r=0,39 ; \mathrm{p}<0,05)$. Babacan liderlik algısı yüksek olan çalışanların duygusal bağlılık düzeyi de yüksektir (Tablo 6). Görev performansı $(r=0,24 ; p<0,05)$, bağlamsal performans $(r=0,46 ; p<0,05)$ ve genel olarak çalışan performansı $(\mathrm{r}=0,38 ; \mathrm{p}<0,05)$ ile duygusal bağlılık arasında pozitif yönlü ve anlamlı ilişki tespit edilmiştir. Duygusal bağlılık düzeyi yüksek olan çalışanların görev, bağlamsal ve genel olarak çalışma performansı da yüksektir (Tablo 6).

Babacan liderlik algısının görev performansı üzerindeki etkisini gösteren regresyon analizi sonuçları Tablo 7'de yer almaktadir.

Tablo 7. Babacan Liderlik Algısının Görev Performansı Üzerindeki Etkisine Ait Regresyon Analizi Sonuçları

\begin{tabular}{lccccc}
\hline Bağımsız Değişkenler & B & SНв & $\boldsymbol{\beta}$ & $\mathbf{t}$ & $\mathbf{p}$ \\
\hline Sabit & 3,719 & 0,137 & & 27,155 & 0,000 \\
Babacan Liderlik Alg1sı & 0,122 & 0,042 & 0,203 & 2,917 & $\mathbf{0 , 0 0 4}$ \\
\hline $\mathrm{R}^{2}=0,041 \quad \Delta \mathrm{R}^{2}=0,036$ & & & & & \\
$\mathrm{~F}(1 ; 304)=8,508 \quad \mathrm{p}=0,004$ & & & & &
\end{tabular}

Babacan liderlik algısı ile görev performansı arasındaki ilişkiyi gösteren modelin uygundur $\left(\mathrm{F}_{(1 ; 198)}=8,51\right.$; $\mathrm{p}<0,05)$. Babacan liderlik algısı, görev performansındaki değişimin yaklaşık \%4'ünü açıklamaktadır $\left(\Delta \mathrm{R}^{2}=0,036\right)$ (Tablo 7).

Regresyon katsayıları ve anlamlılığına ilişkin t testi sonuçlarına göre babacan liderlik algısının, görev performansı üzerinde pozitif yönlü ve anlamlı etkiye sahip olduğu bulgusuna ulaşılmıştır $(\beta=0,20$; $t=2,92$; $\mathrm{p}<0,05)$. Elde edilen bulgulara göre çalışanların babacan liderlik algısının yükselmesi görev performanslarının artmasına neden olmaktadır.

Regresyon analizi sonuçlarına göre babacan liderlik algısının, görev performansı üzerindeki etkisine ait matematiksel model aşağıdaki gibidir:

Görev Performansı $=3,72+0,20 *$ babacan liderlik algisı

Babacan liderlik algısının duygusal bağlılık üzerindeki etkisini gösteren regresyon analizi değerleri Tablo 8 'de yer almaktadır. 
Z. Hatipoğlu - G. Akduman - B. Demir 11/1 (2019) 279-292

Tablo 8. Babacan Liderlik Algısının Duygusal Bağlılık Üzerindeki Etkisine Ait Regresyon Analizi Sonuçları

\begin{tabular}{lccccc}
\hline Bağımsız Değişkenler & B & SHв & $\boldsymbol{\beta}$ & $\mathbf{t}$ & $\mathbf{p}$ \\
\hline Sabit & 2,148 & 0,200 & & 10,734 & 0,000 \\
Babacan Liderlik Alg1S1 & 0,363 & 0,061 & 0,389 & 5,938 & $\mathbf{0 , 0 0 0}$ \\
\hline $\mathrm{R}^{2}=0,151 \quad \Delta \mathrm{R}^{2}=0,147$ & & & & \\
$\mathrm{~F}_{(1 ; 304)=35,265 \quad \mathrm{p}=0,000}$ & & & & \\
\hline
\end{tabular}

Babacan liderlik algısı ile duygusal bağlılık arasındaki ilişkiyi gösteren modelin uygun olduğu görülmektedir $\left(\mathrm{F}_{(1 ; 198)}=35,26 ; \mathrm{p}<0,05\right)$. Babacan liderlik alg1sı, duygusal bağllıktaki değişimin yaklaşık $\% 15^{\prime}$ ini açılamaktadır $\left(\Delta \mathrm{R}^{2}=0,147\right)$ (Tablo 8).

Regresyon katsayıları ve anlamlılığına ilişkin $t$ testi sonuçlarına göre babacan liderlik algısının, duygusal bağlllık üzerinde pozitif yönlü ve anlamlı etkiye sahip olduğu tespit edilmiştir $(\beta=0,39 ; t=5,94 ; p<0,05)$. Elde edilen bulgulara göre çalışanların babacan liderlik algısının yüksekliği duygusal bağlılık düzeylerinin yükselmesine neden olmaktadır.

Regresyon analizi sonuçlarına göre babacan liderlik algısının, duygusal bağlılık üzerindeki etkisine ait matematiksel model şu şekildedir: Duygusal Bă̆gllık =2,15 +0,39*babacan liderlik algısı

Bu durumda araştırma hipotezlerine ilişkin değerlendirme şu şekildedir:

H1: Babacan liderlik algısının görev performansı üzerinde anlamlı etkisi vardır.

$\mathrm{H}_{1}$ Kabul: Babacan liderlik algısının görev performansı üzerinde pozitif yönlü ve anlamlı etkisi vardır.

$\mathrm{H}_{2}$ : Babacan liderlik algısının duygusal bağlılık üzerinde anlamlı etkisi vardır.

$\mathrm{H}_{2}$ Kabul: Babacan liderlik algısının duygusal bağlılık üzerinde pozitif yönlü ve anlamlı etkisi vardır.

\section{Sonuç}

Araştırma sonuçlarına göre, katılımcıların babacan liderlik algılarının orta düzeyde olduğu, performans algılarının yüksek düzeyde olduğu ve duygusal bağlllıklarının orta düzeyde olduğu tespit edilmiştir. Bu veriye göre katılımcılar performanslarını genel olarak diğer iki değişkenden daha olumlu değerlendirmektedirler.

Demografik faktörlere göre detaylar incelendiğinde; performans algısının, babacan liderlik algısının ve duygusal bağlılığın cinsiyete göre anlamlı bir farklılık göstermediği ancak kuşaklar boyutunda bazı farklılıklar olduğu tespit edilmiştir. Buna göre; babacan liderlik algısı ve performans algısı kuşaklara göre farklılık göstermezken; X kuşağında duygusal bağlılık, Y kuşağına göre anlamlı düzeyde daha yüksektir.

Çalışma süresi dikkate alındığında kuşaklara ilişkin bulgulara benzer şekilde; babacan liderlik algısı ve performans algısı kuşaklara göre farklılık göstermemektedir. Ancak duygusal bağlılık çalışma süresine göre anlamlı farklılık göstermektedir. Mevcut şirketteki çalışma süresi 10 yıl ve üstü olan çalışanların duygusal bağlılık puanları, mevcut şirketteki çalışma süresi 9 yıl ve daha az olan çalışanların puanlarından anlamlı düzeyde daha yüksektir.

Babacan liderlik algısı ile görev performansı ve duygusal bağlılık arasında pozitif yönlü ve anlamlı ilişki tespit edilmiştir. Babacan liderlik algısı yüksek olan çalışanların görev performansları ve duygusal bağlılık düzeyleri yüksektir. Duygusal bağlılık düzeyi yüksek olan çalışanların görev, bağlamsal ve genel olarak çalışma performansı da yüksektir. Babacan liderlik algısı, görev performansındaki değişimin yaklaşık \%4'ünü açıklamaktadır. Babacan liderlik algısı, duygusal bağlılıktaki değişimin ise yaklaşık \%15'ini açıklamaktadır.

Elde edilen bulgulara göre çalışanların babacan liderlik algısının yükselmesi görev performanslarının artmasına neden olmaktadir. 
Elde edilen bulgulara göre çalışanların babacan liderlik algısının yüksekliği duygusal bağlılık düzeylerinin yükselmesine neden olmaktadır.

Araştırma sonuçlarımız babacan liderlik tarzının hem görev performansını hem de duygusal bağlılı̆̆ı etkilediğini göstermektedir. Ancak örgütlerin başarısında önemli bir faktör olan duygusal bağlılığın yaş ve kıdem dikkate alındığında farklılık gösterdiği; Y kuşağının ve aynı şirkette 9 yıl ve daha az süre çalışmış olanların duygusal bağlılık düzeylerinin $X$ kuşağından ve 10 yıl üzeri kıdemi olan çalışanlardan daha düşük olduğu sonucuna ulaşılmıştır. Ülkemizde birliktelik duygusunun ve aile ortamının imece kültürünün etkisinde kaldığı, Batı, Kuzey Avrupa ve Amerika ile karşılaştırıldığında karşılıklı bağımlılığın yüksek düzeyde olduğu ifade edilmektedir (Baltaş, 2013:45). Ancak değişen toplum yapısı iş dünyasını ve çalışanların beklentilerini de değiştirmektedir. Dolayısıyla yöneticilerin ve araştırmacıların bu değişimleri dikkate almaları, farklı kuşakların beklentilerini anlayarak doğru motivasyon araçları kullanmaları ve kıdeme bağlı bu duygusal bağlılığın örgüt performansı üzerindeki etkilerini incelemeleri önerilebilir. Araştırmanın kolayda örnekleme yöntemiyle çevrimiçi olarak ulaşılan 200 çalışanla kısıtlı olması sonuçların genellebilirliğini sınırlandırmaktadır. Araştırma kapsamının daha çok katılımcıyla genişletilmesi, örgüt kültürünün liderlik algisına etkisi, duygusal bağlllı̆̆ın somut performans göstergelerini ne düzeyde etkilediği ve kişilik yapısının babacan liderlik algısına etkisi gibi faktörleri de ele alan benzer çalışmaların yapılmasının literatüre katkı sağlayacağı düşünülmektedir.

\section{Kaynakça}

Ağca, V. ve Ertan, H. (2008). Duygusal Bağlılık İçsel Motivasyon İlişkisi: Antalya'da Beş Yıldızlı Otellerde Bir İnceleme. Afyon Kocatepe Üniversitesi İ.İ.B.F. Dergisi, 10(2), ss.135-156.

Akar, H. (2018). İşletmelerde Yetenek Yönetimi Uygulamalarının Örgütsel Bağlılık ve Çalışan Performansına Etkisi. Bahçeşehir Üniversitesi Sosyal Bilimler Enstitüsü, Yayımlanmamış Yüksek Lisans Tezi.

Akdemir, A. (2018). Liderlik ve Vizyon Yönetimi (Birinci Baskı). İstanbul: Beta Basım Yayın Dağıtım.

Akdemir, B. ve Çalış, D. (2016). Duygusal Bağlılık ve İşgören Performası Arasındaki İlişkiye Yönelik Bir Araştırma. International Journal of Social Science, (46), ss.343-357.

Armstrong, M. (2016). Armstrong'un Stratejik İnsan Kaynakları Yönetimi El Kitabı. Çeviri Editörü: Prof.Dr. Yonca Deniz Gürol, Evrim Gemici. Nobel Yayınları. İstanbul.

Arsezen, O., Saltik, I. A. ve Babacan, S. (2015). The Relationship Between Paternalistic Leadership And Business Performance in Small Tourism Businesses: The Moderating Role Of Affective Organizational Commitment. Procedia Social and Behavioral Scienence, 207, ss.90-97.

Arshadi, N., Hayavi, G. (2013). The Effect of Perceived Organizational Support on Affective Commitment and Job Performance: Mediating role of OBSE. Procedia Social and Behavioral Sciences, 84, 739-743.

Ansari, M. A., Ahmad, Z.A. \& Aafaqi, R. (2004), Organizational Leadership in the Malaysian Context. In Leading in High Growth Asia: Managing Relationship for Teamwork and Change, Chapter 5. ss. 109138.

Aycan, Z. (2006). Paternalism. In U. Kim, K. S. Yang, \& K. K. Hwang (Eds.), Indigenous and Cultural Psychology: Understanding People in Context. (pp. 445-466), New York: Springer.

Aycan, Zeynep; Rabindra, Kanungo; Manuel, Mendonca, Kaicheng, Yu, Jürgen, Deller, Günter, Stahl; Kurshid, Anwar (2000), "Impact of culture on human resource management practices: A 10country comparison." Applied Psycho-logy, 49(1), ss.192-221.

Bağcl, Z., (2014), Çalışanların İş Doyumunun Görev ve Bağlamsal Performansları Üzerindeki Etkisi, Yönetim ve Ekonomi Araştırmaları Dergisi, 24(1), ss. 58-72.

Balay R. (2000). Yönetici ve Öğretmenlerde Örgütsel Bağlılık. Nobel Yayın Dağıtım, İstanbul. 
Barutçugil,İ. (2015). Performans Yönetimi, Kariyer Yayıncılık. İstanbul.

Bilal, A. ve Maryam, R. (2015), "The Relationship Between Workplace Spirituality and Innovative Work Behavior: The Mediating Role of Perceived Person-Organization Fit." Journal of Management, Spirituality \& Religion, 12(4), ss.329-353.

Brewster, C. ve Mayrhofer, W. (2012). Handbook of Research on Comparative Human Resource Management. Edward Elgar Publishing. USA.

Briscoe, D.R. ve Claus, L.M. (2008). Employee Performance Management: Policies and Practices in Multinational Enterprises. Edited by: Arup Varma, Pawan S.Budhwar ve Angelo Denisi. Routledge Publishing. London.

Büyüköztürk, Ş. (2011). Sosyal Bilimler İçin Veri Analizi El Kitabı. 14. Baskı. Ankara: PEGEM Akademi.

Casson H. N. (2006). Çalışanlara Altın Öğütler. Hayat Yayıncılık, İstanbul.

Cerit, Y. (2012), Paternalistik liderlik ile yöneticiden ve işin doğasından doyum arasındaki ilişki. Ondokuz Mayıs Üniversitesi Eğitim Fakültesi Dergisi, 31, no.2:35-56.

Chen, X. P., Eberly, M. B., Chiang, T. J., Farh, J. L., ve Cheng, B. S. (2014). Affective Trust in Chinese Leaders: Linking Paternalistic Leadership to Employee Performance. Journal of Management, 40(3), ss. 796819.

Cheng, B.S., Chou, L.F., Wu, T.Y., Huang, M.P. ve Farh, J.F. (2004). Paternalistic Lea $d$ dership and Subordinate Responses: Establishing a Leadership Model in Chinese Organizations. Asian Journal of Social Psychology, 7(1), ss.89-117.

Chan, S. C., ve Mak, W. M. (2012). Benevolent Leadership and Follower Performance: The Mediating Role of Leader-Member Exchange (LMX). Asia Pacific Journal of Management, 29(2), ss.285-301.

Çetin, C. Arslan, M.L. ve Dinç, E. (2015). İnsan Kaynakları Yönetimi. Beta Yayınları. 4.Baskı. İstanbul.

Ellinger, E. A., Musgrove, C. C., Ellinger, A. D., Bachrach, D. G., Elmadă̆, A. B., Wang, Y. L. (2013). Investments in Social Capital on Service Employee Commitment And Performance. Influences of Organizational, (66), ss.1124-1133.

Erben, Gül S ve Güneşer, Ayşe B. (2008). "The Relationship Between Paternalistic Leadership and Organizational Commitment: Investigating The Role of Climate Regarding Ethics." Journal of Business Ethics, 82(4), ss. 955-968.

Eser G., (2007). Etik İklim ve Yöneticiye Güvenin Örgüte Bağl1lı̆ga Etkisi. Yüksek Lisans Tezi. Marmara Üniversitesi Sosyal Bilimler Enstitüsü, İstanbul.

Esty, D. C., Winston, A. S. (2006). Green to Gold: How Smart Companies Use Environmental Strategy to Innovate, Create Value, and Build Competitive Advantage. New Haven: Yale University Press.

Farh, Jiing-Lih, ve Bor-Shiuan Cheng (2000). A Cultural Analysis of Paternalistic Leadership in Chinese Organizations." Management and Organizations in the Chinese Context. Palgrave Macmillan, London, ss. $84-127$.

Göncü, A., Aycan, Z. ve Johnson, R. E. (2014). Effects of Paternalistic and Transformational Leadership on Follower Outcomes." International Journal of Management and Business, 5(1), ss. 36-58.

Grant, A. M., Dutton, J. E. ve Rosso, B. D. (2008). Giving Commitment: Employee Support Programs and The Prosocial Sensemaking Process. Academy of Management Journal, 51, ss.898-918.

Harrison, D. A., Newman, D. A., Roth, P. L. (2006). How İmportant Are Job Attitudes? Meta- $\quad$ Analytic Comparisons of İntegrative Behavioral Outcomes and Time Sequences. Academy of Management Journal, 49(2), ss. 305-325.

Kanten, P. ve Kanten, S. (2016). Örgütlerde Davranışın Aydınlık ve Karanlık Yüzü. Nobel Akademik Yayıncilık, İstanbul. 
Z. Hatipoğlu - G. Akduman - B. Demir 11/1 (2019) 279-292

Kaya, N. ve Selçuk, S. (2007). Bireysel Başarı Güdüsü Organizasyonel Bağlılıgı Nasıl Etkiler?. Doğuş Üniversitesi Dergisi, 8(2), ss.175-190.

Köksal, O. (2011). Bir Kültürel Liderlik Paradoksu: Paternalizm. Mustafa Kemal University Journal of Social Sciences Institute ,8(15), ss.101-122.

Köroğlu, A. (2018). Örgütsel Destek ve Hizmetkar Liderliğin Duygusal Bağlllık Üzerindeki Etkisinin İncelenmesi: Uygulamalı Bir Araştırma, Bayburt Üniversitesi Sosyal Bilimler Enstitüsü, Yayımlanmamış Yüksek Lisans Tezi. Bayburt.

Kurt, İ. (2015). Paternalist Liderlik İle Çalışanların İşlerine Yaratıcı Katılım Algıları Arasındaki İlişkiyi Araştırmaya Yönelik Bir Çalışma." Sosyal ve Beşeri Bilimler Dergisi, 5(1), ss.321- 330.

Lim, B. C., ve Ployhart, R. E. (2004). Transformational Leadership: Relations to The Five-Factor Model and Team Performance in Typical and Maximum Contexts. Journal of Applied Psychology, 89(4), s. 610.

Luecke, R. (2015). Performans Yönetimi. Çeviri: Aslı ÖZER. Türkiye İş Bankası Kültür Yayınları.

Luthans, F. (1995). Organizational Behavior. 7th Edition. McGraw-Hill Inc., New York.

Martínez, P.G. (2003). Paternalism as a Positive Form of Leader-Subordinate Exchange: Evidence From Mexico." Management Research: Journal of the Iberoamerican Academy of $\quad$ Management, 1(3), ss. 227-242.

May, D. R., Gilson, R. L., ve Harter, L. M. (2004). The Psychological Conditions of Meaningfulness, Safety, and Availability and The Engagement Of The Human Spirit At Work. Journal of Occupational and Organizational Psychology, 77, ss.11-37.

Mete, Y.A ve Serin, H. (2015). Okul Yöneticilerinin Babacan Liderlik Davranışı İle Öğretmenlerin Örgütsel Vatandaşlık ve Örgütsel Sinizm Davranışları Arasındaki İlişki. Hasan Âli Yücel Eğitim Fakültesi Dergisi, 12(2) ss.147-159.

Meyer, J. P., Stanley, D. J., Herscovitch, L. ve Topolnytsky, L. (2002). Affective, Continuance, and Normative Commitment to The Organization: A Meta-Analysis of Antecedents, Correlates, and Consequences. Journal of Vocational Behavior, 61, ss.20-52.

Mullins, L.J. (2016). Management and Organizational Behaviour. 11th Edition, Pearson, NewYork.

Myers, D.G. (2005). Exploring Psychology (Sixth edition in modules). New York: Worth Publishers.

Paauwe, J. ve Farndale, E. (2017). Strategy, HRM, and Performance. Second Edition. Oxford University Press.

Pellegrini. E. K \& Scandura. T. A. (2006). Leader-member exchange (LMX), paternalism, and delegation in the Turkish business culture: An empirical investigation. Journal of international business studies 37(2). ss. 264-279.

Peng, M. W., Yuan Lu, Oded, S. ve Wang, D.Y.L. (2001). Treasures in The China House: A Review of Management and Organizational Research on Greater China. Journal of Business Research, 52(2), ss. 95-110.

Pieper, J. R., Greenwald, J. M. ve Schlachter, S. D. (2018). Motivating Employee Referrals: The Interactive Effects of The Referral Bonus, Perceived Risk in Referring, and Affective Commitment. Human Resource Management, 57, ss.1159-1174.

Podsakoff, P. M., MacKenzie, S. B., ve Bommer, W. H. (1996). Transformational Leader Behaviors and Substitutes for Leadership as Determinants of Employee Satisfaction, Commitment, Trust, and Organizational Citizenship Behaviors. Journal of Management, 22(2), ss.259-298.

Poon, J. M. L. (2013). Relationships Among Perceived Career Support, Affective Commitment, and Work Engagement. International Journal of Psychology, 48(6), ss.1148-1155.

Poon, J. M. L. (2010). Affective Commitment, Employee Cynicism, and Work Engagement. Singapore Management Review, 32, ss. 47-62. 
Porter, L. W., Steers, R. M., Mowday, R, T. ve Boulian, P. V. (1974). Organizational Commitment, Job Satisfaction and Turnover Among Psychiatric Technicians. Journal of Applied Psychology, 59, ss.603609.

Pulakos, E.D. (2007). Applied Measurement. Editörler: Whetzel, D.L. ve Wheaton, G.R. Lawrence Erlbaum Associates Publisher. London.

Rafiq Awan, M., ve Mahmood, K. (2010). Relationship Among Leadership Style, Organizational Culture and Employee Commitment in University Libraries. Library Management, 31(4/5), ss.253-266.

Rehman, M. ve B. Afsar (2012), The Impact of Paternalistic Leadership on Organization Commitment and Organization Citizenship Behaviour. Journal of Business Management and Applied Economics, 5, ss.148-159.

Robbins S. P., Judge, T. A. (2012). Örgütsel Davranış (Organizational Behaviour). Çeviri Editörü: Prof. Dr. İnci Erdem, 14. Basımdan Çeviri, Nobel: İstanbul.

Shahin, A. I.\& Wright P. L. (2004). Leadership in the context of culture: An Egyptian perspective. Leadership \& Organization Development Journal 25(6). ss. 499-511.

Silin, R. H. (1976), Leadership and values: The organization of Large-Scale Taiwanese Enterprises (62). Harvard University Asia Center.

Soydan, S. (2011). Creating a Family or Loyalty-Based Framework: The Effects of Paternalistic Leadership on Workplace Bullying. Journal of Business Ethics, 99(2),ss. 217-231.

Şendoğdu, A. A ve Erdirençelebi, M. (2014). Paternalist Liderlik ile Örgütsel Vatandaşlık Davranışı Arasındaki İlişkiye Yönelik bir Araştırma. Sosyal Ekonomik Araştırmalar Dergisi, 14(27), ss.253-274.

Tanrıverdi, H., Koçaslan, G. (2018). Mesleki ve Örgütsel Duygusal Bağlllık Arasındaki İlişki: Tütün Eksperleri ve Tütün Teknolojisi Mühendisleri Üzerine Bir Araştırma. Elektronik Sosyal Bilimler Dergisi, 17(65), ss.248-261.

Uhl-Bien, M., Pamela S. T., George B. G., Mitsuru W. (1990). Company paternalism and the hiddeninvestment process: Identification of the "right type" for line managers in leading Japanese organizations. Group \& Organization Studies 15 (4). ss. 414-430.

Walumbwa, F. O., Avolio, B. J., ve Zhu, W. (2008). How Transformational Leadership Weaves it's Influence on Individual Job Performance: The Role of Identification and Efficacy Beliefs. Personnel Psychology, 61(4), ss.793-825.

Westwood, R. (1997). "Harmony and patriarchy: The Cultural Basis For Paternalistic Headship Among the Overseas Chinese", Organization Studies, 18(3), ss.445-480.

Whitmore,J. (2015). Performans İçin Koçluk. Paloma Yayınları. İstanbul.

Wren, Daniel. A. (2005), The History of Management Thought. John Wiley \& Sons.

Yelboğa, A. (2006). Kişilik Özellikleri ve İş Performansı Arasındaki İlişkinin İncelenmesi, "İş,Güç" Endüstri İlişkileri ve İnsan Kaynakları Dergisi, 8(2), ss. 196-211.

Yorulmaz, M. (2018). Tersane Çalışanlarının Duygusal Bağlılık Düzeylerinin İş Performansları Üzerindeki Etkisi: Yalova Örneği. Uluslararası Sosyal Araştırmalar Dergisi, 11(56), ss.1869- 876.

Zatzick, C. D., Deery, S. J. ve Iverson, R. D. (2015). Understanding The Determinants of Who Gets Laid Off: Does Affectıve Organizational Commitment Matter? Human Resource Management, 54(6), ss.877-891. 